\title{
Reproductive Health and Bodily Integrity in Tanzania
}

\author{
Dr. Judith Westeneng ${ }^{\mathrm{a}} \&$ Dr. Ben D’Exelle ${ }^{\mathrm{b}}$
}

a Rutgers, Postbus 9022, 3506 GA UTRECHT, the Netherlands

\& Amsterdam Institute for Social Science Research (AISSR), University of Amsterdam.

T: +31642232306

F: +31302319387

E: jwesteneng@hotmail.com

b University of East Anglia, School of International Development, Norwich, United Kingdom

\section{SUMMARY}

Several policy initiatives support the empowerment of women to improve their reproductive health. Little is known, however, about the inverse effect that reproductive health might have on women's empowerment. Women are pressured to conform to their reproductive role, and an inability to do so might affect their empowerment, including control over their own body. This study uses a panel dataset of 504 married women in Northern Tanzania. We find that women who suffered a pregnancy loss show more tolerant views of partner violence (regr. coefficient -0.363 ; p-value: 0.001 ), and that child mortality lowers their perceived control over the sexual relationship with their spouse (odds ratio 0.262 ; p-value: 0.016 ). The number of children alive did not affect bodily integrity. These results confirm that women's bodily integrity is partly dependent on the ability to fulfil their reproductive role. They strengthen the case for policies and programmes that improve women's reproductive health, and underline the importance of counselling after pregnancy or child loss.

Keywords. Reproductive health, bodily integrity, empowerment, pregnancy loss, intimate partner violence, child mortality, Sub-Saharan Africa, Tanzania 
ACKNOWLEDGEMENTS: We acknowledge support from the Radboud University Nijmegen in the Netherlands, where this study was coordinated from and the corresponding author was employed at the time of the study. We also gratefully acknowledge financial support of the PopDev program of NWO-WOTRO in partnership with the William and Flora Hewlett Foundation. We highly appreciate the collaboration with Dr. Switbert Kamazima from Muhimbili University of Health and Allied Sciences (MUHAS) from Tanzania and the support from the Tanzanian National Bureau of Statistics. We also thank Bart van Rijsbergen, Janine Huisman and fourteen Tanzanian research assistants for their support during the fieldwork and Ruerd Ruben, Charles Picavet, as well as anonymous reviewers for their valuable comments on the paper.

\section{INTRODUCTION}

Sexual and reproductive health has received growing attention among policy-makers since the 1994 International Conference on Population and Development in Cairo (Sen and Batliwala, 2000). It requires that "people are able to have a satisfying and safe sex life and that they have the capability to reproduce and the freedom to decide if, when and how often to do so" (UNPOPIN et al., 1994). Since then, a large literature has looked at determinants and consequences of reproductive health problems, with a growing number of studies focusing on the potential of women's empowerment to improve reproductive health, including fertility and the use of reproductive health services (e.g. Schuler et al., 1997, Hindin, 2000, Beegle et al., 2001, Larsen and Hollos, 2003, Carroon et al., 2014, Shimamoto and Gipson, 2015, Westeneng and D'Exelle, 2015, Blackstone, 2016, Olorunsaiye et al., 2017).

Little is known, however, about the inverse relationship: the influence of reproductive health on women's empowerment. ${ }^{1}$ Given the important reproductive role of women, it may be that if women are unable to conform to that role, this will affect their empowerment. Improving our understanding of this inverse relationship can be important to maximize the effectiveness of policies and programs that aim to improve women's reproductive health. 
An important empowerment dimension, closely related to reproductive health, is women's bodily integrity, i.e. women being in control of and being the sole authority in making decisions about their own body (Patosalmi, 2009). This includes control over sexuality and the absence of domestic violence (Sen and Batliwala, 2000, Mathur, 2008). ${ }^{2}$ In many areas of the world, women do not have full control over their own body and are unable to exercise their right (if any) to make choices regarding their sexuality. A woman is generally identified with reproduction, childbearing and rearing. The control over sexuality and reproduction is central to unequal gender relations, rooted in patriarchal systems, which pressure women to conform to dominant prescribed roles (Sen and Batliwala, 2000, Mathur, 2008, Kabeer, 2011).

At the same time, fulfilling their reproductive role is an important source of women's social status. This is documented by a wide range of studies, including more theoretical and qualitatively informed papers (e.g. Boserup, 1985, Das Gupta, 1995), research using quantitative analyses of large-scale DHS data (e.g. Arestoff and Djemai, 2013, presenting data from five Sub-Saharan countries), as well as studies using a qualitative or mixed method approach (e.g. Larsen et al., 2010, with a study from Nigeria). According to various scholars women's social status increases with age and is strongly related to their reproductive role. Consequently, childless women tend to be stigmatized (McCloskey et al., 2005, Boserup, 1985, Larsen et al., 2010, Dhont et al., 2011, Fledderjohann, 2012), and miscarriages or stillbirths might deteriorate women's position, as they are often held responsible for the pregnancy loss (Frøen et al., 2011, Heazell et al., 2016)).

Given the pressure on women to conform to their reproductive role and the social status they obtain when successfully fulfilling this role, an important question would be to look at how their bodily integrity is affected by an inability to conform to this role. Would this lower women's control over their sexuality? Would an inability to fulfill this role influence their own views on domestic violence? 
In this article, we address these questions by analysing to what extent reproductive health affects bodily integrity. To this end, we make use of a panel data set of married women in Northern Tanzania from 2004 and 2010 and estimate the effects of pregnancy loss and child mortality on women's views on partner violence and their control over the sexual relationship with their spouse.

\section{SETTING}

Tanzania has been characterized by several decades of political stability, and mixed attention to reproductive, maternal, newborn and child health. The country has showed mixed results in achieving Millennium Development Goals 3 and 5: impressive progress has been made with regards to increasing child survival, but newborn and maternal health have remained behind, as shown by poor progress in reducing stillbirths and low uptake of contraceptive methods and high unmet need (Afnan-Holmes et al., 2015). We specifically selected the Lake Zone region (consisting of three regions bordering Lake Victoria: Kagera, Mwanza, and Mara) in Northwest Tanzania as our study area, because contraceptive use is among the lowest in the country, and fertility rates (7.3 in Kagera, 6.3 in Mwanza and 7.0 in Mara) and the proportion of home deliveries are among the highest (67.5 per cent in Kagera, 52.4 in Mwanza and 68.5 in Mara, versus 52.7 per cent nationally), resulting in high reproductive health vulnerability (NBS, 2005). The area is characterised by a patriarchal system, where polygynous marriages are relatively common. It is a predominantly rural region (only ten percent living in an urban area), dominated by agriculture and some fishing activities.

In rural Tanzania, poverty rates (as measured by the fulfilment of basic needs) have declined, yet remain considerable: in 200732.7 per cent of the households lived below the poverty line, which reduced to 27.5 per cent in 2011/12 (NBS, 2014). Among the key assets of 
rural families in Tanzania are land, livestock and labour. In most (patrilineal) areas (like our study area), women are usually excluded from ownership or inheritance rights over land. Men generally have authority in decision-making concerning food production and sale of food crops, yet women work on average more hours on the land compared to men, reflecting distinct gender roles (Holmboe-Ottesen and Wandel, 1991, Ellis and Mdoe, 2003). In 2004, 86 per cent of the women in the country were employed, most of them in agriculture (NBS, 2005), however most women's work is unpaid. Women are less likely than men to have the full say over their earnings, especially in rural areas. Moreover, men have a larger control over decision-making regarding daily household issues.

Rural women are considered the upholders of traditional life, and are idealised as both hard-working and fulfilling the role of care-taker of the family and children (as described in Northern, patrilineal Tanzania in Haram, 2005). Marriage at a young age, large age differences between spouses, polygyny and low educational levels reflect women's low status. Women sometimes have little say in their own marriage and divorce, as well as in major decisions for their children (Boserup, 1985). In the past decades, however, economic involvement of women has increased as well as unemployment among men, which has eroded these patriarchal relations and challenged the traditional role of men as breadwinner. Such social change, combined with higher educational levels, has resulted in increasing age at marriage, particularly in urban areas (Hattori and Larsen, 2007).

According to national-level data from 2010, roughly $43 \%$ of ever-married or partnered women have ever experienced physical or sexual violence from an intimate partner, and 36\% experienced it in the past year before the interview, yet the figures vary strongly by region. Whereas only $6 . \%$ of women in North Pemba have ever experienced physical violence, this rate is $70.5 \%$ in Dodoma (and $50.4 \%$ in the Lake Zone). Sexual violence rates are lowest in 
North Pemba as well (3.5) and highest in Mara (32.5\%) (with 27.8\% in the overall Lake Zone region) (NBS, 2011, Vyas and Heise, 2016).

\section{RELATED LITERATURE}

(a) The effect of bodily integrity on reproductive health

Very few studies have investigated the effect of reproductive health on bodily integrity, defined as women's control over their own body, which includes control over sexuality and the absence of domestic violence. There are, however, several studies that have documented the effect of bodily integrity on reproductive health.

First, some studies have described how violence against women influences reproductive health. For example, Alio, Nana and Salihu (2009) found in Cameroon that women who ever reported partner violence were fifty per cent more likely to have suffered at least one pregnancy loss. Analysing ten Demographic and Health Surveys, Hindin, Kishor and Ansara (2008) concluded that violence is consistently correlated with unintended pregnancies and higher odds of abortions, miscarriages and stillbirths. A similar study including ten countries worldwide (including Tanzania) using the WHO Multi-country Study on Women's Health and Domestic Violence concluded that women with a history of intimate partner violence have higher odds of unintended pregnancies, abortion, miscarriage and stillbirths (Pallitto et al., 2013). A study in Tanzania found that women who reported intimate partner violence were 1.6 times as likely to report a pregnancy loss and even 1.9 times as likely to report an induced abortion (Stöckl et al., 2012). The latter study suggests four possible pathways, all considering violence as the determinant. 
Similarly, some studies have documented the association between women's control over their sexual relations and reproductive health. The extent to which a woman is able to negotiate the terms of sexual act or relationship, also referred to as sexual agency or sexual empowerment, reflects her capacity to fulfil her own sexual enjoyment, to seek health care services and to protect herself against unwanted pregnancy, disease, and unwanted sexual acts (Dixon-Mueller, 1993).

Most studies that relate sexual agency to reproductive health focus on the use of contraceptives in order to reduce the risk of pregnancies and disease. Blanc (2001, p. 190) describes how "Gender-based power relations can have a direct effect on the ability of partners to acquire information relevant to their reproductive health, on their ability to take decisions related to their health, and on their ability to take action to protect or improve their health or the health of those who depend on them." As an example, she mentions the ability to negotiate condom use. This link has been empirically tested and confirmed by various authors. For example, a study in the USA (mainly among Latinos) concluded that $52 \%$ of inconsistent condom use was attributable to low sexual relationship power (Pulerwitz et al., 2002). Another study in Uganda, drawing on both a survey and focus group discussions, concludes that a sense of personal control over fertility outcomes is instrumental in negotiating condom use (Blanc and Wolff, 2001). Using DHS data from Ghana, Crissman et al. (2012) find that sexual empowerment is correlated with a higher likelihood of using contraceptive methods. Finally, a quantitative study from seven countries in West and Central Africa reports that women who reject intimate partner violence are more likely to use contraceptive methods (Olorunsaiye et al., 2017). 
While existing evidence has mainly focused on the effect of bodily integrity (in the form of control over sexuality and absence of domestic violence) on reproductive health, the inverse relation is equally plausible and has not been documented well. Yet, the literature does give clues for possible mechanisms. Das Gupta (1995) compares the life course perspectives of women's autonomy between northern European societies on the one hand, and India, China and Bangladesh on the other hand. Whereas women in European societies have high autonomy shortly after marriage, which decreases when a woman reaches old age; the reverse pattern is found in Asian societies. Shortly after marriage women experience very little autonomy. It rises slowly with age and the number of children born. It peaks when the woman has acquired the status of mother-in-law and grandmother.

A similar pattern is observed in Sub-Saharan Africa. Ester Boserup (1985) states it very strongly: "Traditionally, the status of African women has been that of non-adults. [...] Most often they have no say in their own marriage and divorce. [...] girls are told from a young age to be obedient and to bear many children (p. 388)." A quantitative study covering five subSaharan countries (Ethiopia, Malawi, Rwanda, Uganda and Zimbabwe) (Arestoff and Djemai, 2013) finds that women's empowerment - although only measured by a dummy variable indicating rejection of intimate partner violence - increases with age, which is in line with Das Gupta (1995) and Boserup (1985). However, this paper shows that empowerment is also subject to social change, i.e. younger cohorts are more empowered than their (grand)mothers at their age. According to the paper, the number of sons does not influence the effect of age or cohort, but has an independent effect on empowerment (Arestoff and Djemai, 2013). A mixed methods study (using a survey among 100 infertile and 100 fertile women, as well as in-depth interviews) from Nigeria describes various stages to womanhood, including the onset of menses, to marriage and childbearing. The latter is necessary in attaining full womanhood, and 
childless women were not allowed to attend certain meetings, and were more likely divorced. The results were strongest for women in patrilineal communities (Larsen et al., 2010). Hence, in contrast to European societies, women's autonomy is strongly dependent on their reproductive role.

As Ryder (2010, p. 613) notes: "Often the only way for a woman to earn esteem is to contribute to the survival of the group by bearing healthy sons." Being an important way to gain status, it is presumably an incentive for high fertility (Mason, 1987). Blanc (2001) follows acknowledging that "[...] outcomes within the domains of sexual and reproductive health can have a reciprocal effect on the balance of power within sexual relationships. For example, having children can increase women's relative power in a relationship (p.190-1)." This is further confirmed by Sen and Batliwala (Sen and Batliwala, 2000, p. 24) who state that "the subordination of women has often been achieved through the subjugation and control of their sexual and reproductive lives, with often disastrous consequences to their health and status. [One of] the manifestations of this includes [...] being blamed and victimized for reproductive outcomes (bearing daughters instead of sons, or for being infertile)."

Such claims are also made in studies describing (psychological and social) consequences of infertility, miscarriages and stillbirths. For example, a paper describing effects in both high income countries (HICs) and low and middle income countries (LMICs), states that pregnancy loss (especially of the first birth) robs parents of the opportunity to form a new identity as a parent (Akker, 2011). Focusing on developing countries specifically, a review of qualitative studies (Rouchou, 2013) describes social, psychological and economic consequences of infertility for both men and women. For women this includes the risk of divorce and loss of inheritance, higher risk to violence, loss of identity as mother and later as elder, loss of family and community support. For men, marital instability and demoralisation of a man, negatively affecting his status as individual, affecting his economic chances are reported. Stillbirths, in 
addition, can lead to economic costs (health care, funeral, loss of income), more severe psychological effects including depression and anxiety, and a feeling of being valued less by society (Frøen et al., 2011, Heazell et al., 2016). A systematic literature review (Burden et al., 2016) on consequences of stillbirths confirms this result. This paper - dominated by articles on HICs - indicates that consequences such as grief and loss of identity are found in both HIC and LMICs. In LMICs, economic consequences (health care costs, funeral) and social consequences as stigma, blame, abuse and rejection are more often described.

Murphy (2012), in a study in the UK, describes that after a stillbirth, women lose the identity of 'moral mother' and risk being stigmatized. It is based on the assumption that during pregnancy a woman is in full control, which implies that in case of stillbirth they are blamed for maternal incompetency. Several other studies have confirmed that women might be held responsible by their spouses for the pregnancy loss or for being 'too expensive' when medical care is needed (e.g. in Burkina Faso: Storeng et al., 2008). ${ }^{3}$

\section{(c) Existing evidence on Tanzania}

For Tanzania, our study area, two relevant studies merit discussion. First, Haws and colleagues (2010) collected qualitative narratives of fifty women in rural southern Tanzania (Muslim dominated area) who suffered infertility, miscarriage, stillbirth or an early neonatal death. They conclude that pregnancy loss is seen as a non-event, and is not mourned openly. Stillbirths and miscarriages are concealed, because women are afraid they will be accused of having induced the loss. Such accusations can lead to stigma, and the denial of economic and emotional support. The authors conclude (p. 1765): "Women's low social status in many lowresource settings limits their sexual negotiating power and access to education and health care, rendering them vulnerable to victimization, blame, and stigma, especially in reproductive 
matters." Hence, vulnerable women are most at risk to both pregnancy loss and the subsequent stigma, abuse, possible divorce and a denial of economic and emotional support.

The second, anthropological, study is conducted by Wembah-Rashid (1996) who depicts a rather less pessimistic account of the experiences of pregnancy loss in Southeast Tanzania. Women are less often held responsible for the pregnancy loss. External factors are more prominently identified as causes, and husbands more often than women were incurred culpability. For example, husband's unfaithfulness to his wife was seen as cause of recurrent pregnancy loss.

The difference in these accounts most likely reflects a difference between patriarchal and matrilineal settings, respectively. As Plummer and colleagues (2008) explain in their study on the Sukuma in Mwanza (Northern Tanzania), in patrilineal and patrilocal societies, a payment of bride wealth at marriage traditionally secured men's entitlement to any offspring, giving men the right to divorce their wife if she had induced an abortion. This likely contributes to the concealment of the pregnancy loss.

Very few scholars have tried to test whether reproductive health affects women's risk of violence or control over their sexual relations in a quantitative way. The only reference for Tanzania that we are aware of is McCloskey and colleagues (2005), who found in urban Tanzania that one out of five married women experience intimate partner abuse and one out of four have ever experienced such violence. This risk was higher for infertile women. The study, however, is unable to determine the directionality of the effect. ${ }^{4}$

\section{(d) Hypotheses}

The literature review has shown that women's social status is strongly related to their reproductive role. We focus on an empowerment domain which is most closely linked to 
reproductive health: bodily integrity, for which we include two sub-domains: attitudes towards intimate partner violence, and perceived control over the sexual relationship with the spouse. While the occurrence of violence and the acceptance thereof tend to be correlated, we prefer to use the acceptance of violence. As it measures the extent to which women have internalized norms that give men the right to discipline women (NBS, 2005), we consider it to be more closely related to empowerment than the actual experience of violence. For reproductive health outcomes, we focus on the experience of child mortality (after a live birth), and pregnancy loss (including miscarriages, abortions and stillbirths).

Drawing from the (often anthropological) accounts described above, we formulate the following hypothesized mechanisms which link reproductive health outcomes to bodily integrity. Firstly, after a loss of a pregnancy or child, women may feel pressured to demonstrate and prove their reproductive qualities. We therefore expect a reduction in the perceived control over the sexual relationship with her partner. Secondly, the literature has pointed out that women may be blamed for the loss. This could lead to women acknowledging this responsibility, and accepting some form of discipline (whether or not the woman is actually disciplined). As such, we hypothesize that the loss of a pregnancy or child leads to an increased acceptance of intimate partner violence. Finally, whereas we expect negative effects from negative health events, we hypothesize that women's bodily integrity is likely to increase with the number of children born and alive.

\section{DATA AND METHODS}

In this section, we describe the data collection, and explain how we construct the main variables for analysis, as well as our econometric identification strategy. 


\section{(a) Empirical strategy}

In the summer of 2010, we re-interviewed a sub-sample of women from the Demographic Health Survey 2004 in the Lake Zone Region. Approximately 1,200 women were interviewed in the Lake Zone Region in 2004, and in 2010 we were able to re-interview 807 of them. ${ }^{5}$ As the NBS (National Bureau of Statistics) collected the data in 2004, regional officers of the NBS visited the enumeration areas to track the women to be interviewed, and to ask for permission and consent for the re-interview prior to the visit by the research team. The willingness to participate in the interview was high with only two women refusing to participate. Yet, a large share of the women could not be traced after six years. Especially women who were not yet married in 2004 got married and migrated elsewhere. Moreover, some were not present in the village during the visit. Where possible, we tried to contact these women via family members, although this proved to be difficult in more urbanized areas where neighbours were no longer in touch or who had migrated as well. Moreover, the response rate also dependent on the willingness of the local leader to support the research team, which, specifically in one enumeration area, led to an extremely high attrition rate. Finally, resources were scarce to return to sites on multiple occasions hoping to trace more women.

The household- and women's questionnaires of 2004 and 2010 were largely the same, except for the biomedical information and the extended children's nutrition section, which were not collected in 2010. The questions used in this paper were all phrased exactly the same in both years. For the analyses, we select women who were married or living together in both 2004 and 2010 (which results in a sample of 504 women), and estimate the following specification:

$$
Y_{i t}=\beta_{0}+\beta_{1} \cdot X_{i t}+\beta_{2} \cdot Z_{i t}+\sigma_{i}+\varepsilon_{i t}
$$

with $Y_{i t}$ being bodily integrity of individual $i$ in year $t, X_{i t}$ being a vector of the various reproductive health outcomes and $Z_{i t}$ a vector of control variables; $\sigma_{i}$ are individual fixed 
effects and $\varepsilon_{i t}$ is an idiosyncratic error which is allowed to vary over time. ${ }^{6}$ We have chosen to apply a fixed effects model. First, whereas regular OLS estimates may be biased due to unknown time-invariant factors affecting both empowerment and reproductive health (e.g. unobserved personality characteristics, ability or preferences), fixed effects models are not affected by this problem. More specifically, fixed effects models permit regressors to be endogenous on the condition that they are only correlated with the time invariant component of the error (Cameron and Trivedi, 2009).

\section{(b) Measuring Bodily Integrity and reproductive health}

We measure bodily integrity $\left(Y_{i t}\right)$ with two indicators: women's reported attitude towards intimate partner violence and their perceived control over the sexual relationship with their husband. To construct the first indicator, we use the question "Is a husband justified in beating his wife in the following situations?" We use five binary variables, each of them having a score of 1 if the interviewee disapproves, zero otherwise, corresponding to each of the following five situations: if she goes out without telling him; if she neglects the children; if she argues with him; if she refuses to have sex with him; if she burns the food. The factor score, which combines all five items (using principle factor analysis, eigenvalue of first factor is 2.66 , Cronbach's alpha .84), is then used as indicator, with a higher score indicating a less tolerant view towards domestic violence.

To construct the indicator of perceived control over sexual relationships we use the two questions "Can you say no to your husband if you do not want to have sexual intercourse?" and "Could you ask your husband to use a condom if you wanted him to?" We combine these questions into one score by setting it equal to one if a woman answers positively to both questions, zero otherwise. 
As reproductive health variables $\left(X_{i t}\right)$ we include: 1$)$ number of children (born to the woman) deceased (after a live birth, at any age); 2) the number of pregnancy losses (miscarriage, induced abortion or stillbirth) in the past five years ${ }^{7}$; and 3 ) the number of children alive and living in the same household as the mother. We expect that the effect of pregnancy loss is temporary, justifying the chosen time frame of five years. To the contrary, we assume that the effect of the number of children alive as well as child mortality can have a lasting effect. Therefore we do not limit the measurement to the number of children born in the past five years, and we use the number of children ever deceased.

\section{(c) Control variables}

To avoid omitted variable bias, we include control variables $\left(Z_{i t}\right)$ at the individual and household level that we expect to correlate with both the dependent variables as well as with the reproductive health determinants as described above. In a first step we include infertility. A woman is defined infecund in the following cases: 1) If she has had a hysterectomy; 2) If she declares she is infecund; 3) If she is in menopause; 4) If she is not pregnant, not breastfeeding and has had no menstruation for six months or longer; or 5) If she has been married in the past five years, has used no contraceptive methods, is not pregnant and has not given birth in the past five years. We also control for media exposure, using a dummy variable equal to one if the woman listens to the radio regularly, as it is the most common media and the most likely used media for health awareness raising programmes (Rogers et al., 1999). Moreover, exposure to mass media has been found to be a relevant determinant of the attitude towards intimate partner violence (Flood and Pease, 2009). We also control for household wealth, which we calculate by an asset index score, as wealth is found to be correlated with empowerment (Mabsout and Van Staveren, 2010, WB, 2012). Poverty is also considered a determinant for 
reproductive health outcomes, partly due to lower access and uptake of health services and higher risks due to poorer living conditions (e.g. Westeneng and D'Exelle, 2015). Finally, we add the year of the interview in the model to control for period effects. ${ }^{8}$

In a second step we add further control variables, which we think might be important to include but at the same time might create new endogeneity problems, as the directionality of their effect is difficult to determine. We have identified two such control variables: 1) economic empowerment and 2) household composition. These variables are likely correlated with the time-variant error term, so that the endogeneity they potentially create is not solved by applying fixed effects. To deal with this issue, instrumental variable analysis is often used. Unfortunately, proper instruments that meet the strict theoretical and empirical requirements are not available. As a pragmatic approach we run models with and without these control variables to test the robustness of the effects of pregnancy loss and child mortality on bodily integrity.

Economic empowerment is found to reduce women's reproductive health vulnerability (Westeneng and D'Exelle, 2015), and is likely to be correlated with bodily integrity as both are domains of empowerment. To control for the interviewee's economic empowerment we include an indicator that measures women's control over money. The interviewed women were asked whether they exert any control over the money needed to buy four different items (food, clothes, medicines, and toiletries). A factor score is used as indicator for the control over money, a higher score indicating a higher level of control. We further control for whether the woman is in a polygynous marriage and whether the husband and the mother-in-law live in the same house as the interviewee (Wong and Levine, 1992). 


\section{RESULTS}

In this section, we present descriptive statistics, followed by regression analyses. We conclude by checking and correcting for attrition bias.

\section{(a) Descriptive statistics}

Table 1 reports the descriptive statistics. We observe that the average scores on attitudes towards domestic violence and perceived control over the sexual relationships show negative trends. For example, in 200473.8 per cent of the women answered 'no' to the question "Is a husband allowed to beat his wife if she refuses to have sex with him", while only 60.1 per cent of these women gave this same answer in 2010. We find a similar trend in perceived control over their sexual relationship. In 2004, 78.8 per cent answered positively to the question "Can you say no to your husband if you don't want to have sex with him", which dropped to 61.3 per cent in 2010. We observe an even stronger decline for the question "Can you ask your husband to use a condom" (66.7 to 43.1 per cent $){ }^{9}$

- Insert Table 1 here -

The average number of children ever born rose from 4.2 in 2004 to 5.1 in 2010. Approximately 63 per cent of the women in the sample reported a birth between 2004 and 2010. However, not all children survived or lived in the household with their biological mother. On average one boy per three mothers and one girl per two mothers lived elsewhere. Pregnancy loss and the death of children are common. One in every three women reported they had a terminated pregnancy or stillbirth at least once in her life. Approximately 12 per cent of the 
women indicated that they had experienced such an event between 2004 and 2010. Over 56 per cent reported that they had ever lost a child, and one out of five women indicated that she had lost one between 2004 and 2010. The number of infecund women below the age of 40 years increased between 2004 and 2010.

On average, wealth increased between 2004 and 2010. Exposure to radio decreased: whereas $65 \%$ of the women listened to the radio regularly in 2004 , this dropped to $56.3 \%$ in 2010. One possible explanation is the increase in exposure to television. We further observe that women's reported control over money increased between 2004 and 2010. We also observe that approximately 28 per cent of the 504 women included in the analyses were in a polygynous marriage.

\section{(b) Regression analyses}

Table 2 presents the estimated effects of reproductive health events on both measurements of bodily integrity. For both dependent variables - attitude towards spousal violence and control over sexual relationships - we present three models. In a first model (models 1 and 4 for the respective dependent variables) we only include pregnancy loss, child mortality, and the number of children alive and living with the mother. As explained before, we then add control variables in two steps. In models 2 and 5 we add infertility, as well as exposure to media, household level wealth and year of survey. In models 3 and 6 control over money, nature of marriage (polygynous or not), and whether the spouse and mother-in-law live in the household are added as well.

- Insert Table 2 here - 
In model 1, which estimates effects on the attitude towards spousal violence, we find that pregnancy loss - number of miscarriages, abortions or stillbirths in the five years preceding the interview - shows the expected negative effect. Losing a pregnancy seems to lower the rejection of spousal violence (or increase the acceptance of it). This remains robust to adding the control variables, as we observe in models 2 and 3. The number of daughters and sons alive show a strong negative effect in model 1, i.e. if the number of children alive increases, women tend to report more tolerant views towards domestic violence, but these effects are no longer significant once a control for the year of the interview is included. In models 2 and 3, period effects proves to be significant, pointing to the negative trend of the attitude towards spousal violence. Out of the other control variables in model 3, control over money shows a positive effect, indicating that women who become economically more empowered also show a stronger rejection of domestic violence.

Models 4 to 6 estimate the influence of the reproductive health indicators on women's perceived control over sexual relationship with their spouse. We report the odds ratios, which makes it easier to interpret the size of the effects. Child mortality shows a robust negative effect. Women who report the death of a child tend to experience a reduction in perceived control over the sexual relationship with their partners. In model 4, we find that for women who reported having lost one child, the odds of having perceived power over the sexual relationship with their partner is only $39.2 \%$ of the odds of those women who did not report to have lost one child. The odds ratio is even smaller for women who lost two or more children (0.207). Yet, whereas both categories have a significant coefficient in model 4, only the highest category (at least two children deceased) remains robust in both models 5 and $6^{10}$. The effect is slightly reduced to an odds ratio of .262 in model 6.

Again, we see that the effect of the number of children alive shows an unexpected negative effect in model 4, yet these effects are not statistically significant once we control for the year 
of the survey. Out of the control variables, the period effect proves to be a significant determinant. Also, women who moved into a polygynous marriage and those whose husband started to live in the same household show a positive trend in the perceived control over the sexual relationship with their spouse.

- Insert Table 3 here -

\section{(c) Checking and correcting for biases}

The estimated effects might be affected by attrition bias in the following two ways. First, as we were unable to re-interview all women of the original sample, the key question becomes whether the 35 per cent attrition in our data is random. If it is not and the likelihood of being interviewed in the second wave is related to some of the parameters in the model, estimates might be biased (Ziliak and Kniesner, 1998, Outes-Leon and Dercon, 2008). Second, we have limited the sample to women who were married in both 2004 and 2010. As a result we have excluded from the analysis women who divorced after 2004, which might lead to a second source of attrition bias if marital status is correlated with reproductive health outcomes and bodily integrity (for example, because more empowered women are more likely to divorce).

To detect possible non-random attrition, we performed three tests. First, we compare the mean scores of our parameters in 2004 between the attriting and non-attriting group, in which attrition includes both women who were not re-interviewed and those excluded based on marital status (Table 3). The mean scores for our dependent variables differ barely between the two groups. Most of the reproductive health variables, as well as some control variables do correlate with attrition. The non-attriting group more often experienced child mortality and pregnancy loss, and have on average more living children as well, which can be explained by the fact that this group was already married 2004, and as such the attritting group includes 
younger, unmarried women. Moreover, the non-attriting group is on average less wealthy, more likely to be in a polygynous marriage and having the spouse living in the same household. This indication of non-randomness is confirmed by a second test, a Wald statistic which we calculated based on a model estimating the probability of attriting (Chi2: 74.78; Prob>Chi2: .0000). Finally, we performed two Becketti, Gould, Lillard and Welch (BGLW) tests (F: 3.34; Prob>F: .0006 for domestic violence; and F: 0.86; Prob>F: .6118 for control over sexual relationship), which led to the same conclusion, but only for one of the two regressions (attitude towards spousal violence) (Outes-Leon and Dercon, 2008, Baulch and Quisumbing, 2011).

To correct the regression estimates for possible attrition bias, we calculated inverse probability weights. The procedure (Following: Baulch and Quisumbing, 2011, Fitzgerald et al., 1998) involves estimating two probit regressions, the first being:

$$
R_{i}=X_{i 1} \gamma+a_{i 1} \delta+v_{i}
$$

In this probit regression, $R_{i}=1$ if the individual remains in the sample and $R_{i}=0$ for attritors; $X_{i 1}$ represents the variables in the model unrelated to attrition and $a_{i 1}$ are the auxiliary variables, variables that are expected to be predictors of retention. As auxiliary variables, we use three types of variables. First, we use significant individual characteristics which are already in the model as control variables. Second, we add dummy variables for each interviewer, as a proxy measurement for the quality of the interview. Finally, we add a variable indicating the position a woman had in the household in 2004. This variable is equal to one if the respective woman was head or spouse of the head of household, zero otherwise. We do so, as mostly younger girls who were living as a daughter (in-law) in the household in 2004, migrated between 2004 and 2010 to start their own household. In the second probit regression, these (significant) auxiliary variables are excluded:

$$
R_{i}=X_{i 1} \gamma+\varphi_{i}
$$


The weights are calculated as the ratio of predicted probabilities from these two probit regressions (probabilities of equation 3 divided by the probabilities of equation 2):

$$
W_{i}=\frac{P^{r}}{P^{u}}
$$

with $P^{u}$ being the predicted probability of the unrestricted equation (i.e. equation 2 ) and $P^{r}$ being the predicted probability of the restricted equation (i.e. without the auxiliary variables). These inverse probability weights give lower weight to households who have characteristics similar to non-attriting households, to correct the relative oversampling of these households. We have weighted the analyses using these inverse probability weights (see Table 4). We see that the main conclusions drawn before remain unchanged. More specifically, there is no significant effect of the number of children alive. Moreover, we find that women who have lost two or more children have weaker control over their sexual relationship with their spouse; the size of the effect has slightly increased (odds ratio changed from .262 to .226). Pregnancy loss shows a similar (but smaller) negative effect on the attitude towards spousal violence: women who have reported a pregnancy loss, become more violence accepting (albeit now only significant at the $5 \%$ level). In sum, our main effects are not strongly affected by selection bias.

\section{- $\quad$ Insert Table 4 here -}

Although our findings are not strongly affected by selection bias, it merits attention to look more closely into the role of marital status in this study. Would the results be different if we were to focus on women who divorced between 2004 and 2010, or those that got married in that time period? We have grouped the total sample in four categories: 1) in union in both years; 2) in union in 2004, but separated in 2010; 3) never married in 2004, in union in 2010; and 4) other (e.g. widowed, or never married in 2004 and separated in 2010). Running the same 
analyses for these different groups is not feasible for two reasons. First, the perceived control over sexual relationships is only posed to women in union at the time of the survey. As such, this analyses can only be performed on the group that was in union in both years. Secondly, the number of observations in the other groups is very low ( $\mathrm{N}=49,77,174$ respectively), making it undesirable to run analyses on these separate samples. In order to give an idea of differences in possible results, we have compared the descriptive statistics between the four groups, and have run the regression analyses on the attitude towards domestic violence including all women and taking marital status as control variable. The Tables A1 and A2 are found in the Annex. There are no differences between the four groups of women in their attitude towards domestic violence. To the contrary, women who divorced between 2004 and 2010, showed more control over sexual relationships in 2004 compared to women who remained in union. Moreover, the divorcees also had more control over money in both years, and were wealthier. This does suggest that these divorcees were more empowered in 2004 compared to women who remained in union. Caution is needed, however, due to the low number of divorcees. The regression analyses shows no effect of marital status on the attitude towards domestic violence (confirming the descriptive statistics). The effect of pregnancy loss reduces in significance though (two-sided p-value of 0.060).

\section{(d) Testing alternative time frames}

As a final robustness check, we discuss and further analyse the reference point of our focal independent variables. As explained before, we have chosen to measure the number of children alive and those deceased using a lifetime approach, whereas we have limited the number of pregnancy losses to the past five years, hypothesizing that the effect of the former two would last longer than the latter. To take a closer look at this assumption, we run the analyses again: 
once with all three variables measured over the past five years, and once applying a lifetime approach.

Some minor changes had to be made to the variables. First, the number of pregnancy losses ever experienced is not available. As such, we resort to a dummy variable equal to one if a woman has experienced at least one loss in her life. In 2004, $20 \%$ indicated to have experienced at least one; in 2010 this figure increased to $23 \%$, a relatively small increase. The second change considers the number of children alive. For the five year time frame we limit the measurement to the number of children alive and living with the mother and born in the past five years. Due to lower numbers, the categories are slightly different. The number of children deceased in the past five years is limited. In 2004, $14.2 \%$ had lost one child in the past five years, and 3.0\% had lost more than one child. In 2010, these figures were considerably lower: $6.3 \%$ and $0.9 \%$ respectively.

Table A3 in the Annex presents the results. We see that the effect of pregnancy loss on the attitude towards domestic violence is weaker when applying a lifetime approach. If controlled for possible attrition bias (results not shown but available upon request), this effect is reduced even further (two sided p-value .128). The effect of child mortality on the perceived control over sexual relationships shows a strong effect when applying a lifetime approach, but the effect is not statistically significant when we limit the measurement to the deaths in the past five years.

We could therefore conclude that pregnancy losses have a strong short-term effect and a weak longer term effect. The opposite seems to be true for child mortality: we found a strong, robust effect for child mortality on the long term, but no effect on the short-term. This is counterintuitive, and it might be due to low statistical power, considering the low number of deaths in the past five years. 


\section{DISCUSSION AND CONCLUSION}

In this study we investigated the effect of fertility, pregnancy loss and child mortality on bodily integrity. We started with the assumption that being able to successfully fulfill their reproductive role will improve women's status and therefore her bodily integrity, in terms of their rejection of domestic violence and their control over the sexual relationship with their husband. Moreover, we assumed that negative reproductive health issues are locally interpreted as a failure of women to fulfil their reproductive role. This in turn would have a negative influence on women's bodily integrity. Making use of a panel data set in Northern Tanzania, we found evidence that supports this latter hypothesis: women who reported a pregnancy loss reported more tolerant views of partner violence over time, while child mortality decreased their perceived control over the sexual relationship with their husband. No effect was found for the number of living children.

Whereas the work of, for example, Blanc (2001), Ryder (2010) and Arestoff and Djemai (2013) indicates that giving births to children, and especially boys, increases women's relative power in the household, our study does show no effect of the number of children alive on bodily integrity. The results on pregnancy loss and child mortality are in line with an anthropological account of Haws et al. (2010) in Tanzania, who describe that women are afraid of being accused of inducing a miscarriage or stillbirth and subsequent stigmatizing consequences, including denial of economic and emotional support. This idea is supported by other scholars, such as Sen and Batliwala (2000, p. 24), who state that being blamed and victimized for reproductive health outcomes is one manifestation of the control men tend to hold over women. Furthermore, it highlights the importance of paying attention to the consequences of reproductive health problems. As Heazell and colleagues (2016) and Frøen and colleagues (2011) conclude: stillbirths are highly prevalent, are largely avoidable, and have serious consequences, but have 
largely been neglected. As they put it: "mothers' own aspiration - a live baby - has been absent from the global health agenda" (Frøen et al., 2011, p. 1353).

Our findings are very important for programmes or initiatives that aim to improve women's reproductive health. The Millennium Development Goals have been replaced by the Sustainable Development Goals. Both empowerment (under goal five: gender equality) and reproductive health (under goal three: good health and well-being) are included. This study has shown the linkages between and mutual dependency of these goals. For example, we already knew that gender equality is related to poverty (goal number one) and influenced by education (number four), and this paper adds the influence of reproductive health outcomes (goal three). As such, in reaching these SDGs, rather than treating the goals as isolated islands, these interlinkages should not be ignored.

More specifically, policies usually focus on strengthening women's autonomy first as prerequisite for improving women's reproductive health. The idea is that women would then have better access to reproductive health services such as contraceptive use, prenatal care, delivery care and postnatal care, which would increase their reproductive health. Our study indicates that there might be an important feedback loop: better reproductive health in terms of lower child mortality and pregnancy loss, increases women's bodily integrity. This strengthens the case for programs and initiatives that aim to improve women's reproductive health.

Furthermore, the conclusion that empowerment, and specifically norms and beliefs about gender roles and sexuality influence reproductive health outcomes, has led to the logical conclusion that interventions should focus on gender transformative programming, including discussions (either in separate groups for men and women, or for couples) on gender roles and sexuality norms. Male involvement in care throughout the pregnancy is often encouraged with this idea in mind. The effect of reproductive health on women's bodily integrity demonstrated in our study adds another element to these recommendations: the need for additional 
counselling after a miscarriage, stillbirth or the death of a child, in order to prevent women to bear the largest burden of this loss.

This study is prone to three main limitations. First, we had to limit our sample to women who were married in both years of survey. It would be interesting to study the relationship with marital status using a larger dataset. Such a study could answer the question if divorce is more likely after certain reproductive health outcomes, and if more empowered women are more likely to divorce or not. Secondly, our paper has not been able to answer why pregnancy loss does have an effect on the attitude towards violence, but not on the perceived control over the sexual relationship with the husband, nor why the opposite is true for child mortality. Finally, further research could distinguish between miscarriages, stillbirths and induced abortions. In our study, we were unable to do so, but it is likely that having an induced abortion has a stronger effect than a spontaneous miscarriage (Haws et al., 2010), or whether the spouse considers the pregnancy loss as self-induced or spontaneous. However, we have to acknowledge that this will be a major challenge considering the sensitivity of the subject and likely underreporting. Qualitative data and interpretation could give valuable contributions to this, as they could provide insights in the different meanings given to the various reproductive health events. They could also reveal local explanations about causal mechanisms that interviewees understood as having contributed to certain outcomes and associations. Future research could also add to this study by studying coping skills after reproductive health events, and specifically looking into the role of communication between the spouses.

\section{REFERENCES}

Afnan-Holmes, H., Magoma, M., John, T., Levira, F., Msemo, G., Armstrong, C. E., MartínezÁlvarez, M., Kerber, k., Kihinga, C., Makuwani, A., Rusibamayila, N., Hussein, A. \& Lawn, J. E. 2015. Tanzania's Countdown to 2015: An Analysis of Two Decades of 
Progress and Gaps for Reproductive, Maternal, Newborn, and Child Health, to Inform Priorities for Post-2015. Lancet Global Health, 3, e396-409.

Akker, v. d., Olga B.A 2011. The Psychological and Social Consequences of Miscarriage. Expert Review of Obstetrics \& Gynecology, 6, 295-304.

Alio, A. P., Nana, P. N. \& Salihu, H. M. 2009. Spousal Violence and Potentially Preventable Single and Recurrent Spontaneous Fetal Loss in an African Setting: Cross-Sectional Study. Lancet, 373, 318-324.

Arestoff, F. \& Djemai, E. 2013. Women's Empowerment across the Life Cycle and Generations: Evidence from Sub-Saharan Africa. Document de travail UMR DIAL, DT/2013-16.

Baulch, B. \& Quisumbing, A. 2011. Testing and Adjusting for Attrition in Household Panel Data. CPRC Toolkit Note. Chronic Poverty Research Centre.

Beegle, K., Frankenberg, E. \& Thomas, D. 2001. Bargaining Power within Couples and Use of Prenatal and Delivery Care in Indonesia. Studies in Family Planning, 32, 130-146.

Béhague, D. P., Kanhonou, L. G., Filippi, V., Lègonou, S. \& Ronsmans, C. 2008. Pierre Bourdieu and Transformative Agency: A Study of How Patients in Benin Negotiate Blame and Accountability in the Context of Severe Obstetric Events. Sociology of Health \& Illness, 30, 489-510.

Blackstone, S. R. 2016. Women's Empowerment, Household Status and Contraception Use in Ghana. Journal of Biosocial Science, 1-12.

Blanc, A. K. 2001. The Effect of Power in Sexual Relationships on Sexual and Reproductive Health: An Examination of the Evidence. Studies in Family Planning, 32, 189-213.

Blanc, A. K. \& Wolff, B. 2001. Gender and Decision-Making over Condom Use in Two Districts in Uganda. African Journal of Reproductive Health, 5, 15-28. 
Boserup, E. 1985. Economic and Demographic Interrelationships in Sub-Saharan Africa. Population and Development Review, 11, 383-397.

Burden, C., Bradley, S., Storey, C., Ellis, A., Heazell, A. E. P., Downe, S., Cacciatore, J. \& Siassakos, D. 2016. From Grief, Guilt Pain and Stigma to Hope and Pride - a Systematic Review and Meta-Analysis of Mixed-Method Research of the Psychosocial Impact of Stillbirth. BMC Pregnancy and Childbirth, 16, 1-12.

Cameron, A. C. \& Trivedi, P. K. 2009. Microeconomics Using Stata, College Station, Texas, Stata Press

Carroon, M., Speizer, I. S., Fotso, J. C., Akiode, A., Saad, A., Calhoun, L. \& Irani, L. 2014. The Role of Gender Empowerment on Reproductive Health Outcomes in Urban Nigeria. Maternal and Child Health Journal, 18, 307-315.

Crissman, H. P., Adanu, R. M. \& Harlow, S. D. 2012. Women's Sexual Empowerment and Contraceptive Use in Ghana. Studies in Family Planning, 43, 201-212.

Das Gupta, M. 1995. Life Course Perspectives on Women's Autonomy and Health Outcomes. American Anthropoligist, 97, 481-491.

Dhont, N., van de Wijgert, J., Coene, G., Gasarabwe, A. \& Temmerman, M. 2011. 'Mama and Papa Nothing': Living with Infertility among an Urban Population in Kigali, Rwanda. Human Reproduction, 26, 623-629.

Dixon-Mueller, R. 1993. The Sexuality Connection in Reproductive Health. Studies in Family Planning, 24, 269-282.

Ellis, F. \& Mdoe, N. 2003. Livelihoods and Rural Poverty Reduction in Tanzania. World Development, 31, 1367-1384.

Fitzgerald, J., Gottschalk, P. \& Moffitt, R. 1998. An Analysis of Sample Attrition in Panel Data: The Michigan Panel Study of Income Dynamics. The Journal of Human Resources, 33, 251-299. 
Fledderjohann, J. J. 2012. 'Zero Is Not Good for Me': Implications of Infertility in Ghana. Human Reproduction, 27, 1383-1390.

Flood, M. \& Pease, B. 2009. Factors Influencing Attitudes to Violence against Women. Trauma, Violence, \& Abuse, 10, 125-142.

Frøen, J. F., Cacciatore, J., McClure, E. M., Kuti, O., Jokhio, A. H., Islam, M. \& Shiffman, J. 2011. Stillbirths: Why They Matter. Lancet, 377, 1353-1366.

Haram, L. 2005. 'Prostitutes' or Modern Women? Negotiating Respectability in Nortern Tanzania. In: Arnfred, S. (ed.) Re-Thinking Sexualities in Africa. Uppsala: Almqvist \& Wiksell Tryckeri.

Hattori, M. K. \& Larsen, U. 2007. Motherhood Status and Union Formation in Moshi, Tanzania 2002-2003. Population Studies 61, 185-199.

Haws, R. A., Irene, M., Mrisho, M., Schellenberg, J. A., Darmstadt, G. L. \& Winch, P. J. 2010. "These Are Not Good Things for Other People to Know": How Rural Tanzanian Women's Experiences of Pregnancy Loss and Early Neonatal Death May Impact Survey Data Quality. Social Science \& Medicine, 71, 1764-1772.

Heazell, A. E. P., Siassakos, D., Blencowe, H., Burden, C., Bhutta, Z. A., Cacciatore, J., Dang, N., Das, J., Flenady, V., Gold, K. J., Mensah, O. K., Millum, J., Nuzum, D., O'Donoghue, K., Redshaw, M., Rizvi, A., Roberts, T., Saraki, H. E. T., Storey, C., Wojcieszek, A. M. \& Downe, S. 2016. Stillbirths: Economic and Psychosocial Consequences. Lancet, 387, 604-616.

Hindin, M. J. 2000. Women's Autonomy, Women's Status and Fertility-Related Behaviour in Zimbabwe. Population Research and policy Review, 19, 255-282.

Hindin, M. J., Kishor, S. \& Ansara, D. L. 2008. Intimate Partner Violence among Couples in 10 Dhs Countries: Predictors and Health Outcomes. DHS Analytical Studies 18. Calverton, MD USA: Macro International Inc. 
Holmboe-Ottesen, G. \& Wandel, M. 1991. Men's Contribution to the Food and Nutritional Situation in the Tanzanian Household. Ecology of Food and Nutrition, 26, 83-96.

Kabeer, N. 1999. Resources, Agency, Achievements: Reflections on the Measurement of Women's Empowerment. Development and Change, 30, 435-464.

Kabeer, N. 2011. Between Affiliation and Autonomy: Navigating Pathways of Women's Empowerment and Gender Justice in Rural Bangladesh. Development and Change, 42, 499-528.

Larsen, U. \& Hollos, M. 2003. Women's Empowerment and Fertility Decline among the Pare of Kilimanjaro Region, Northern Tanzania. Social Science \& Medicine, 57, 1099-1115.

Larsen, U., Hollos, M., Obono, O. \& Whitehouse, B. 2010. Suffering Infertility: The Impact of Infertility on Women's Life Experiences in Two Nigerian Communities. Journal of Biosocial Science, 42, 787-814.

Lee-Rife, S. M. 2010. Women's Empowerment and Reproductive Experiences over the Lifecourse. Social Science \& Medicine, 71, 634-642.

Mabsout, R. \& Van Staveren, I. 2010. Disentangling Bargaining Power from Individual and Household Level to Institutions: Evidence on Women's Position in Ethiopia. World Development, 38, 783-796.

Malhotra, A., Schuler, S. R. \& Boender, C. 2002. Measuring Women's Empowerment as a Variable in International Development. Washington DC: World Bank.

Mason, K. O. 1987. The Impact of Women's Social Position on Fertility in Developing Countries. Sociological Forum, 2, 718-745.

Mathur, K. 2008. Body as Space, Body as Site: Bodily Integrity and Women's Empowerment in India. Economic and Political Weekly, XLIII, 24-63. 
McCloskey, L. A., William, C. \& Larsen, U. 2005. Gender Inequality and Intimate Partner Violence among Women in Moshi, Tanzania. International Family Planning Perspectives, 31, 124-130.

Murphy, S. 2012. Reclaiming a Moral Identity: Stillbirth, Stigma and 'Moral Mothers'. Midwifery, 28, 476-480.

NBS 2005. Tanzania Demographic and Health Survey 2004/2005. Dar Es Salaam: National Bureau of Statistics and ORC Macro.

NBS 2011. Tanzania Demographic and Health Survey 2010. Dar es Salaam: National Bureau of Statistics and ORC Macro.

NBS 2014. Household Budget Survey, Main Report 2011/12. Dar-es-Salaam, Tanzania: National Bureau of Statistics.

Nussbaum, M. C. 2003. Capabilities as Fundamental Entitlements: Sen and Social Justice. Feminist Economics, 9, 33-59.

Olorunsaiye, C. Z., Huber, L. B., Laditka, S. B., Shanti, K. \& Boyd, A. S. 2017. Associations between Women's Perceptions of Domestic Violence and Contraceptive Use in Seven Countries in West and Central Africa. Sexual \& Reproductive Healthcare, https://dx.doi.org/10.1016/j.srhc.2017.01.003.

Outes-Leon, I. \& Dercon, S. 2008. Survey Attrition and Attrition Bias in Young Lives. Technical Note No. 5. Oxford: Young Lives.

Pallitto, C. C., García-Moreno, C., Jansen, H. A. F. M., Heise, L., Ellsberg, M. \& Watts, C. 2013. Intimate Partner Violence, Abortion, and Unintended Pregnancy: Results from the Who Multi-Country Study on Women's Health and Domestic Violence. International Journal of Gynecology and Obstetrics, 120, 3-9.

Patosalmi, M. 2009. Bodily Integrity and Conceptions of Subjectivity. Hypatia, 24, 125-141. 
Plummer, M. L., Wamoyi, J., Nyalali, K., Mshana, G., Shigongo, Z., S., Ross, D. A. \& Wight, D. 2008. Aborting and Suspending Pregnancy in Rural Tanzania: An Ethnography of Young People's Beliefs and Practices. Studies in Family Planning, 39, 281-292.

Pulerwitz, J., Amaro, H., DeJong, W., Gortmaker, S. L. \& Rudd, R. 2002. Relationship Power, Condom Use and Hiv Risk among Women in the USA. AIDS CARE, 14, 789-800.

Robeyns, I. 2011. Sen's Capability Approach and Gender Inequality: Selecting Relevant Capabilities. Feminist Economics, 9, 61-92.

Rogers, E. M., Vaughan, P. W., Swalehe, R. M. A., Rao, N., VSvenkerud, P. \& Soo, S. 1999. Effects of an Entertainment-Education Radio Soap Opera on Family Planning Behavior in Tanzania. Studies in Family Planning, 30, 193-211.

Rouchou, B. 2013. Consequences of Infertility in Developing Countries. Perspectives in Public Health, 133, 174-179.

Ryder, N. 2010. Norman Ryder on the Sociology of Fertility Reduction. Population and Development Review, 36, 607-620.

Schuler, S. R., Hashemi, S. M. \& Riley, A. P. 1997. The Influence of Women's Changing Roles and Status in Bagladesh's Fertility Transition: Evidence from a Study of Credit Programs and Contraceptive Use. World Development, 25, 563-575.

Sen, G. \& Batliwala, S. 2000. Empowering Women for Reproductive Rights. In: Presser, H. B. \& Sen, G. (eds.) Women's Empowerment and Demographic Processes. Moving Beyond Cairo. New York: Oxford University Press.

Shimamoto, K. \& Gipson, J. D. 2015. The Relationship of Women's Status and Empowerment with Skilled Birth Attendant Use in Senegal and Tanzania. BMC Pregnancy and Childbirth, 15, 1-11.

Silberschmidt, M. 2001. Disempowerment of Men in Rural and Urban East Africa: Implications for Male Identity and Sexual Behavior. World Development, 29, 657-671. 
Stöckl, H., Filippi, V., Watts, C. \& Mbwambo, J. K. K. 2012. Induced Abortion, Pregnancy Loss and Intimate Partner Violence in Tanzania: A Population Based Study. BMC Pregnancy and Childbirth, 12, 1-12.

Storeng, K. T., Baggaley, R. F., Ganaba, R., Ouattara, F., Akoum, M. S. \& Filippi, V. 2008. Paying the Price: The Cost and Consequences of Emergency Obstetric Care in Burkina Faso. Social Science \& Medicine, 66, 545-557.

UNPOPIN, UN-DEAS \& UNFPA 1994. Guidelines on Reproductive Health. New York: United Nationas Population Information Network (POPIN), UN Population Dividon, Department of Economic and Social Affairs, with support from the UN Population Fund (UNFPA).

Vyas, S. \& Heise, L. 2016. How Do Area-Level Socioeconomic Status and Gender Norms Affect Partner Violence against Women? Evidence from Tanzania. International Journal of Public Health, 61, 971-980.

Vyas, S. \& Watts, C. 2009. How Does Economic Empowerment Affect Women's Risk of Intimate Partner Violence in Low and Middle Income Countries? A Systematic Review of Published Evidence. Journal of International Development, 21, 577-602.

WB 2012. World Development Report 2012: Gender Equality and Development. Washington DC: The World Bank.

Wembah-Rashid, J. A. R. 1996. Explaining Pregnancy Loss in Matrilineal Southeast Tanzania. In: Cecil, R. (ed.) The Anthropology of Pregnancy Loss. Comparative Studies in Miscarriage, Stillbirth and Neonatal Death. Washington D.C.: Berg.

Westeneng, J. \& D'Exelle, B. 2015. How Economic Empowerment Reduces Women's Reproductive Health Vulnerability in Tanzania. The Journal of Development Studies, $51,1459-1474$. 
Wong, R. \& Levine, R. E. 1992. The Effect of Household Structure on Women's Economic Activity and Fertility: Evidence from Recent Mothers in Urban Mexico. Economic Development and Cultural Change, 41, 89-102.

Ziliak, J. P. \& Kniesner, T. J. 1998. The Importance of Sample Attrition in Life Cycle Labor Supply Estimation. The Journal of Human Resources, 33, 507-530. 
Table 1. Descriptive statistics

\begin{tabular}{|c|c|c|c|c|}
\hline & $\begin{array}{l}\text { Mean / percent } \\
\text { (pooled) }\end{array}$ & $\begin{array}{c}\text { Mean / percent } \\
(2004)\end{array}$ & $\begin{array}{c}\text { Mean / percent } \\
(2010)\end{array}$ & $\begin{array}{l}\text { Difference } \\
(2004-10)\end{array}$ \\
\hline \multicolumn{5}{|l|}{ Bodily integrity } \\
\hline Attitude towards spousal violence (index) & 0.032 & 0.209 & -0.146 & $-.356 * * *$ \\
\hline \multicolumn{5}{|l|}{ Beating not justified if: } \\
\hline She goes out without telling husband & $54.8 \%$ & $61.8 \%$ & $47.8 \%$ & $-14.0 \% * * *$ \\
\hline She neglects the children & $46.3 \%$ & $56.3 \%$ & $36.2 \%$ & $-20.1 \% * * *$ \\
\hline She argues with him & $48.0 \%$ & $57.1 \%$ & $38.8 \%$ & $-18.3 \% * * *$ \\
\hline She refuses to have sex with him & $67.0 \%$ & $73.8 \%$ & $60.1 \%$ & $-13.7 \% * * *$ \\
\hline She burns the food & $85.9 \%$ & $87.5 \%$ & $84.4 \%$ & $-3.1 \%$ \\
\hline Control over sexual relationship (index) & $47.4 \%$ & $59.8 \%$ & $35.0 \%$ & $-24.8 \% * * *$ \\
\hline Possible to refuse sex & $70.1 \%$ & $78.8 \%$ & $61.3 \%$ & $-17.5 \% * * *$ \\
\hline Possible to ask husband to use a condom & $54.9 \%$ & $66.7 \%$ & $43.1 \%$ & $-23.6 \% * * *$ \\
\hline \multicolumn{5}{|l|}{ Reproductive health } \\
\hline 0 children alive & $5.4 \%$ & $8.4 \%$ & $2.4 \%$ & $-6.0 \% * * *$ \\
\hline 1-3 children alive & $39.5 \%$ & $49.3 \%$ & $29.7 \%$ & $-19.6 \% * * *$ \\
\hline 4-5 children alive & $28.4 \%$ & $22.6 \%$ & $34.3 \%$ & $11.7 \% * * *$ \\
\hline $6+$ children alive & $26.7 \%$ & $19.8 \%$ & $33.6 \%$ & $13.8 \% * * *$ \\
\hline 0 children deceased & $56.6 \%$ & $60.2 \%$ & $53.0 \%$ & $-7.2 \% * *$ \\
\hline 1 child deceased & $24.6 \%$ & $22.8 \%$ & $26.5 \%$ & $3.7 \%$ \\
\hline $2+$ children deceased & $18.8 \%$ & $17.0 \%$ & $20.5 \%$ & $3.5 \%$ \\
\hline Pregnancy loss (nr in past 5 years) & .115 & .134 & .096 & -0.038 \\
\hline Infecund & $22.3 \%$ & $17.5 \%$ & $27.1 \%$ & $9.6 \% * * *$ \\
\hline \multicolumn{5}{|l|}{ Control variables } \\
\hline Wealth & -.099 & -.178 & -.021 & $0.157^{* * *}$ \\
\hline Radio exposure & $60.7 \%$ & $65.0 \%$ & $56.3 \%$ & $-8.7 \% * *$ \\
\hline Control over money & -.066 & -.145 & .013 & $.158^{* *}$ \\
\hline In polygynous marriage & $28.5 \%$ & $27.8 \%$ & $29.2 \%$ & $1.5 \%$ \\
\hline Spouse living in household & $96.2 \%$ & $95.8 \%$ & $96.6 \%$ & $0.8 \%$ \\
\hline Presence mother-in-law & $7.6 \%$ & $7.4 \%$ & $7.9 \%$ & $0.5 \%$ \\
\hline
\end{tabular}

Notes: Last column: T-values/Z-values reported. Based on two-sided p-values $* * *, * *, *$ indicate significance levels at $1 \%, 5 \%$ and $10 \%$ respectively; sample weights applied; sample limited to non-attritors, and women married in both 2004 and 2010. ${ }^{\text {a Cronbach's alpha } .84}$ 
Table 2. The effect of pregnancy loss and child mortality on bodily integrity

\begin{tabular}{|c|c|c|c|c|c|c|}
\hline & \multicolumn{3}{|c|}{$\begin{array}{l}\text { attitude towards spousal violence } \\
\text { (linear regression coef) }\end{array}$} & \multicolumn{3}{|c|}{$\begin{array}{l}\text { perceived control over sexual } \\
\text { relationships } \\
\text { (odds ratios) }\end{array}$} \\
\hline & (1) & (2) & (3) & (4) & (5) & (6) \\
\hline 0 children deceased & ref & ref & ref & ref & ref & ref \\
\hline 1 child deceased & $\begin{array}{l}-0.045 \\
(0.156)\end{array}$ & $\begin{array}{c}0.047 \\
(0.153)\end{array}$ & $\begin{array}{c}0.045 \\
(0.153)\end{array}$ & $\begin{array}{c}0.392 * * \\
(0.151)\end{array}$ & $\begin{array}{c}0.434 \\
(0.220)\end{array}$ & $\begin{array}{l}0.381^{*} \\
(0.194)\end{array}$ \\
\hline $2+$ children deceased & $\begin{array}{c}0.103 \\
(0.196)\end{array}$ & $\begin{array}{c}0.226 \\
(0.181)\end{array}$ & $\begin{array}{c}0.192 \\
(0.180)\end{array}$ & $\begin{array}{c}0.207 * * * \\
(0.106)\end{array}$ & $\begin{array}{c}0.315^{* *} \\
(0.169)\end{array}$ & $\begin{array}{c}0.262^{* *} \\
(0.146)\end{array}$ \\
\hline Pregnancy loss (nr in past $5 \mathrm{yrs}$ ) & $\begin{array}{c}-0.281 * * * \\
(0.101)\end{array}$ & $\begin{array}{c}-0.342 * * * \\
(0.104)\end{array}$ & $\begin{array}{c}-0.363 * * * \\
(0.109)\end{array}$ & $\begin{array}{c}1.655 \\
(0.649)\end{array}$ & $\begin{array}{c}1.337 \\
(0.572)\end{array}$ & $\begin{array}{l}1.328 \\
(0.641)\end{array}$ \\
\hline 0 children alive & ref & ref & ref & ref & ref & ref \\
\hline 1-3 children alive & $\begin{array}{c}-0.564 * * * \\
(0.206)\end{array}$ & $\begin{array}{l}-0.272 \\
(0.211)\end{array}$ & $\begin{array}{l}-0.222 \\
(0.219)\end{array}$ & $\begin{array}{c}0.187 * * \\
(0.136)\end{array}$ & $\begin{array}{c}0.761 \\
(0.544)\end{array}$ & $\begin{array}{c}0.583 \\
(0.464)\end{array}$ \\
\hline $4-5$ children alive & $\begin{array}{c}-0.949 * * * \\
(0.233)\end{array}$ & $\begin{array}{l}-0.374 \\
(0.263)\end{array}$ & $\begin{array}{c}-0.322 \\
(0.267)\end{array}$ & $\begin{array}{c}0.071 * * * \\
(0.057)\end{array}$ & $\begin{array}{c}0.925 \\
(0.779)\end{array}$ & $\begin{array}{c}0.772 \\
(0.709)\end{array}$ \\
\hline $6+$ children alive & $\begin{array}{c}-1.149 * * * \\
(0.265)\end{array}$ & $\begin{array}{l}-0.323 \\
(0.311)\end{array}$ & $\begin{array}{l}-0.274 \\
(0.314)\end{array}$ & $\begin{array}{c}0.046 * * * \\
(0.044)\end{array}$ & $\begin{array}{c}1.630 \\
(1.739)\end{array}$ & $\begin{array}{c}1.086 \\
(1.219)\end{array}$ \\
\hline \multicolumn{7}{|l|}{ Control variables } \\
\hline infecund & & $\begin{array}{c}0.110 \\
(0.128)\end{array}$ & $\begin{array}{c}0.100 \\
(0.127)\end{array}$ & & $\begin{array}{c}0.854 \\
(0.340)\end{array}$ & $\begin{array}{c}0.896 \\
(0.377)\end{array}$ \\
\hline Radio exposure & & $\begin{array}{c}0.039 \\
(0.093)\end{array}$ & $\begin{array}{c}0.049 \\
(0.093)\end{array}$ & & $\begin{array}{c}1.258 \\
(0.357)\end{array}$ & $\begin{array}{c}1.387 \\
(0.383)\end{array}$ \\
\hline Wealth & & $\begin{array}{c}0.088 \\
(0.100)\end{array}$ & $\begin{array}{c}0.076 \\
(0.108)\end{array}$ & & $\begin{array}{c}1.212 \\
(0.442)\end{array}$ & $\begin{array}{c}0.916 \\
(0.344)\end{array}$ \\
\hline Year of survey & & $\begin{array}{c}-0.378 * * * \\
(0.078)\end{array}$ & $\begin{array}{c}-0.390 * * * \\
(0.079)\end{array}$ & & $\begin{array}{c}0.266^{* * *} * \\
(0.062)\end{array}$ & $\begin{array}{c}0.244 * * * \\
(0.061)\end{array}$ \\
\hline Control over money & & & $\begin{array}{c}0.101 * * \\
(0.048)\end{array}$ & & & $\begin{array}{c}1.235 \\
(0.178)\end{array}$ \\
\hline Polygynous marriage & & & $\begin{array}{c}0.174 \\
(0.151)\end{array}$ & & & $\begin{array}{c}5.588^{* * *} \\
(4.040)\end{array}$ \\
\hline Spouse living in same house & & & $\begin{array}{l}-0.105 \\
(0.235)\end{array}$ & & & $\begin{array}{c}6.536^{* *} \\
(5.316)\end{array}$ \\
\hline Presence mother-in-law & & & $\begin{array}{c}0.150 \\
(0.177)\end{array}$ & & & $\begin{array}{c}0.662 \\
(0.364)\end{array}$ \\
\hline Constant & $\begin{array}{c}0.855^{* * *} \\
(0.205) \\
\end{array}$ & $\begin{array}{c}0.464 * * \\
(0.218) \\
\end{array}$ & $\begin{array}{c}0.476 \\
(0.330) \\
\end{array}$ & - & - & - \\
\hline Number of observations & 1001 & 997 & 994 & 432 & 430 & 428 \\
\hline Number of groups & 504 & 504 & 504 & n.a & n.a & n.a \\
\hline F / Wald chi2 & 5.47 & 6.04 & 5.42 & 23.70 & 60.61 & 62.32 \\
\hline Prob $>$ F / Wald chi2 & .0000 & .0000 & .0000 & .0006 & .0000 & .0000 \\
\hline R-square within / Pseudo R-square & .0599 & .1180 & .1312 & .1212 & .2739 & .3206 \\
\hline
\end{tabular}

Notes: Models 4-6 are conditional logit models, odds ratios presented. Based on two-sided p-values ***,**,* indicate significance levels at $1 \%, 5 \%$ and $10 \%$ respectively; sampling weights applied. 
Table 3. Comparing characteristics of non-attriting and attriting groups in 2004

\begin{tabular}{|c|c|c|c|c|}
\hline & $\begin{array}{l}\text { Non-attriting } \\
\text { group }\end{array}$ & $\begin{array}{l}\text { Attriting } \\
\text { group }\end{array}$ & Difference & $P>|t|$ \\
\hline \multicolumn{5}{|l|}{ Bodily integrity } \\
\hline Attitude towards spousal violence (index) & 0.206 & 0.130 & -0.076 & .224 \\
\hline \multicolumn{5}{|l|}{ Beating not justified if: } \\
\hline She goes out without telling husband & $61.6 \%$ & $62.8 \%$ & $1.2 \%$ & .700 \\
\hline She neglects the children & $56.0 \%$ & $56.8 \%$ & $0.8 \%$ & .817 \\
\hline She argues with him & $56.9 \%$ & $54.2 \%$ & $-2.7 \%$ & .391 \\
\hline She refuses to have sex with him & $73.6 \%$ & $70.2 \%$ & $-3.4 \%$ & .208 \\
\hline She burns the food & $87.4 \%$ & $84.9 \%$ & $-2.5 \%$ & .187 \\
\hline Control over sexual relationship (index) & $59.8 \%$ & $63.5 \%$ & $3.7 \%$ & .312 \\
\hline Possible to refuse sex & $79.0 \%$ & $77.1 \%$ & $-1.9 \%$ & .548 \\
\hline Possible to ask husband to use a condom & $66.8 \%$ & $69.6 \%$ & $2.8 \%$ & .423 \\
\hline \multicolumn{5}{|l|}{ Reproductive health } \\
\hline 0 children deceased & $60.0 \%$ & $72.9 \%$ & $12.9 \%$ & .000 \\
\hline 1 child deceased & $22.8 \%$ & $17.1 \%$ & $-5.7 \%$ & .020 \\
\hline $2+$ children deceased & $17.2 \%$ & $10.0 \%$ & $-7.2 \%$ & .001 \\
\hline Pregnancy loss (nr in past 5 years) & 0.136 & 0.068 & -.068 & .005 \\
\hline 0 children alive & $8.5 \%$ & $32.5 \%$ & $24.0 \%$ & .000 \\
\hline 1-3 children alive & $49.2 \%$ & $40.8 \%$ & $-8.4 \%$ & .007 \\
\hline 4-5 children alive & $22.4 \%$ & $14.1 \%$ & $-8.3 \%$ & .001 \\
\hline $6+$ children alive & $20.0 \%$ & $12.7 \%$ & $-7.3 \%$ & .001 \\
\hline \multicolumn{5}{|l|}{ Control variables } \\
\hline Infecund & $17.2 \%$ & $13.4 \%$ & $-3.8 \%$ & .089 \\
\hline Listens to radio regularly & $65.1 \%$ & $64.2 \%$ & $0.9 \%$ & .759 \\
\hline Control over money & -0.162 & -0.076 & 0.086 & .201 \\
\hline Wealth & -0.184 & 0.177 & 0.361 & .000 \\
\hline In polygynous marriage & $27.0 \%$ & $12.6 \%$ & $-14.4 \%$ & .000 \\
\hline Spouse living in same house & $95.8 \%$ & $86.3 \%$ & $-9.5 \%$ & .000 \\
\hline Presence mother in law & $7.4 \%$ & $5.9 \%$ & $-1.5 \%$ & .303 \\
\hline
\end{tabular}

Notes: sample weights applied; Linearized standard errors reported; $\mathrm{P}>|\mathrm{t}|$ is the result of a two-sided t-test 
Table 4. Controlling for possible selection bias using inverse probability weights

\begin{tabular}{|c|c|c|c|c|}
\hline & \multicolumn{2}{|c|}{$\begin{array}{l}\text { Spousal violence } \\
\text { (linear regression coef) }\end{array}$} & \multicolumn{2}{|c|}{$\begin{array}{l}\text { Control sexual } \\
\text { relationship } \\
\text { (odds ratios) } \\
\end{array}$} \\
\hline & Coef. & St.Er. & Coef. & St.Er. \\
\hline 0 children deceased & ref. & & ref. & \\
\hline 1 child deceased & 0.015 & 0.156 & $0.385^{*}$ & 0.192 \\
\hline $2+$ children deceased & 0.152 & 0.182 & $0.226^{* *}$ & 0.128 \\
\hline Pregnancy loss (nr in past 5 years) & $-0.249 * *$ & 0.110 & 1.521 & 0.739 \\
\hline 0 children alive & ref. & & ref. & \\
\hline $1-3$ children alive & -0.025 & 0.235 & 0.493 & 0.408 \\
\hline 4-5 children alive & -0.167 & 0.275 & 0.614 & 0.579 \\
\hline $6+$ children alive & -0.146 & 0.322 & 0.862 & 0.983 \\
\hline \multicolumn{5}{|l|}{ Control variables } \\
\hline infecund & .059 & 0.129 & 0.910 & 0.388 \\
\hline Radio exposure & 0.036 & 0.099 & 1.346 & 0.398 \\
\hline Wealth & 0.063 & 0.103 & 1.032 & 0.394 \\
\hline Year of survey & -0.326 & 0.085 & $0.243 * * *$ & 0.061 \\
\hline Control over money & $0.090 * *$ & 0.048 & 1.215 & 0.170 \\
\hline In polygynous marriage & 0.178 & 0.154 & $5.703 * *$ & 4.118 \\
\hline Spouse living in same house & 0.049 & 0.264 & $10.743 * * *$ & 9.355 \\
\hline Presence mother-in-law & -0.057 & 0.208 & 0.781 & 0.458 \\
\hline Constant & 0.180 & 0.350 & n.a. & \\
\hline Number of observations & 993 & & 428 & \\
\hline F / Chi2 & 3.57 & & 62.99 & \\
\hline Prob > F / Prob > Chi2 & .0000 & & .0000 & \\
\hline R2 within / Pseudo R2 & .1015 & & .3339 & \\
\hline
\end{tabular}

Notes: Model 2 presents Condition logit estimates, odds ratios presented. Based on two-sided pvalues $* * *, * *, *$ indicate significance levels at $1 \%, 5 \%$ and $10 \%$ respectively; sampling and Inverse probability weights applied in all models. 
Table A1. Comparing characteristics of groups of women, categorized according to marital status

\begin{tabular}{|c|c|c|c|c|c|c|c|c|}
\hline \multirow{3}{*}{$\begin{array}{l}\mathrm{N} \\
\text { Year }\end{array}$} & \multicolumn{2}{|c|}{ Married both years } & \multicolumn{2}{|c|}{$\begin{array}{c}\text { Married/living } \\
\text { together in } 2004, \\
\text { divorced/separated in } \\
2010 \\
\end{array}$} & \multicolumn{2}{|c|}{$\begin{array}{l}\text { Never married in } 2004, \\
\text { married/living together } \\
\text { in } 2010\end{array}$} & \multicolumn{2}{|c|}{ Other } \\
\hline & \multicolumn{2}{|c|}{504} & \multicolumn{2}{|r|}{49} & \multicolumn{2}{|r|}{77} & \multicolumn{2}{|r|}{$174^{\mathrm{a}}$} \\
\hline & 2004 & 2010 & 2004 & 2010 & 2004 & 2010 & 2004 & 2010 \\
\hline \multicolumn{9}{|l|}{ Bodily integrity } \\
\hline $\begin{array}{l}\text { Attitude towards } \\
\text { spousal } \\
\text { violence (index) }\end{array}$ & 0.209 & -0.146 & 0.127 & 0.098 & 0.222 & $0.115 * *$ & 0.144 & -0.019 \\
\hline \multicolumn{9}{|l|}{ Beating not justified if: } \\
\hline $\begin{array}{l}\text { She goes out without } \\
\text { telling husband }\end{array}$ & $61.8 \%$ & $47.8 \%$ & $64.2 \%$ & $56.6 \%$ & $67.4 \%$ & $62.4 \% * *$ & $62.1 \%$ & $55.3 \%$ \\
\hline $\begin{array}{l}\text { She neglects the } \\
\text { children }\end{array}$ & $56.3 \%$ & $36.2 \%$ & $53.3 \%$ & $55.2 \% * *$ & $56.7 \%$ & $47.4 \% *$ & $57.1 \%$ & $46.9 \% * *$ \\
\hline She argues with him & $57.1 \%$ & $38.8 \%$ & $53.8 \%$ & $54.9 \% * *$ & $60.6 \%$ & $47.8 \%$ & $55.8 \%$ & $48.1 \% *$ \\
\hline $\begin{array}{l}\text { She refuses to have sex } \\
\text { with him }\end{array}$ & $73.8 \%$ & $60.1 \%$ & $66.0 \%$ & $62.8 \%$ & $66.0 \%$ & $76.7 \% * * *$ & $62.1 \% * * *$ & $61.6 \%$ \\
\hline She burns the food & $87.5 \%$ & $84.4 \%$ & $77.9 \% *$ & $81.5 \%$ & $85.2 \%$ & $81.5 \%$ & $82.5 \%$ & $75.6 \% * *$ \\
\hline $\begin{array}{l}\text { Control over sexual } \\
\text { relationship (index) }\end{array}$ & $59.8 \%$ & $35.0 \%$ & $75.6 \% * *$ & n.a. & n.a. & $36.0 \%$ & $62.1 \%$ & $50.7 \%$ \\
\hline Possible to refuse sex & $78.8 \%$ & $61.3 \%$ & $86.9 \%$ & n.a. & n.a. & $67.1 \%$ & $74.5 \%$ & $81.2 \% *$ \\
\hline $\begin{array}{l}\text { Possible to ask husband } \\
\text { to use a condom }\end{array}$ & $66.7 \%$ & $43.1 \%$ & $79.7 \% *$ & n.a. & n.a. & $43.0 \%$ & $68.7 \%$ & $50.7 \%$ \\
\hline \multicolumn{9}{|l|}{ Reproductive Health } \\
\hline 0 children deceased & $60.2 \%$ & $53.0 \%$ & $61.7 \%$ & $61.3 \%$ & $95.6 \% * * *$ & $80.8 \% * * *$ & $61.3 \%$ & $58.8 \%$ \\
\hline 1 child deceased & $22.8 \%$ & $26.5 \%$ & $23.6 \%$ & $23.8 \%$ & $4.4 \% * * *$ & $17.4 \%$ & $20.9 \%$ & $21.5 \%$ \\
\hline $2+$ children deceased & $17.0 \%$ & $20.5 \%$ & $14.7 \%$ & $14.9 \%$ & $0.0 \% * * *$ & $1.8 \% * * *$ & $17.8 \%$ & $19.7 \%$ \\
\hline $\begin{array}{l}\text { Pregnancy loss ( } \mathrm{nr} \text { in past } \\
5 \text { years) }\end{array}$ & 0.134 & 0.096 & 0.084 & 0.086 & $0.022 * * *$ & 0.865 & 0.110 & 0.059 \\
\hline 0 children alive & $8.4 \%$ & $2.4 \%$ & $4.3 \%$ & $1.2 \%$ & $84.5 \% * * *$ & $14.0 \% * * *$ & $28.4 \% * * *$ & $19.0 \% * * *$ \\
\hline 1-3 children alive & $49.3 \%$ & $29.7 \%$ & $50.5 \%$ & $39.7 \%$ & $15.5 \% * * *$ & $76.6 \% * * *$ & $34.1 \% * * *$ & $34.7 \%$ \\
\hline 4-5 children alive & $22.6 \%$ & $34.3 \%$ & $23.9 \%$ & $36.8 \%$ & $0.0 \% * * *$ & $8.5 \% * * *$ & $17.8 \%$ & $23.1 \% * *$ \\
\hline $6+$ children alive & $19.8 \%$ & $33.6 \%$ & $21.3 \%$ & $22.3 \%$ & $0.0 \% * * *$ & $0.9 \% * * *$ & $19.7 \%$ & $23.2 \% * *$ \\
\hline \multicolumn{9}{|l|}{ Control variables } \\
\hline Infecund & $17.5 \%$ & $27.1 \%$ & $25.6 \%$ & $36.1 \%$ & $2.4 \% * * *$ & $12.9 \% * *$ & $18.3 \%$ & $27.4 \%$ \\
\hline Listens to radio regularly & $65.0 \%$ & $56.3 \%$ & $76.0 \%$ & $55.9 \%$ & $67.5 \%$ & $72.3 \% * *$ & $53.3 \% * *$ & $47.8 \% *$ \\
\hline Control over money & -0.145 & 0.013 & $0.157 * *$ & $0.609 * * *$ & $-0.735^{* * *}$ & -0.137 & $0.214^{* * *}$ & $0.329 * * *$ \\
\hline Wealth & -0.178 & -0.021 & $0.287 * * *$ & $0.346^{* *}$ & $0.073^{*}$ & $0.510 * * *$ & $0.143 * * *$ & $0.488 * * *$ \\
\hline In polygynous marriage & $27.8 \%$ & $29.2 \%$ & $38.3 \%$ & n.a. & n.a. & $13.6 \% * * *$ & $4.4 \% * * *$ & $3.5 \% * * *$ \\
\hline $\begin{array}{l}\text { Spouse living in same } \\
\text { house }\end{array}$ & $95.8 \%$ & $96.6 \%$ & $76.6 \% * * *$ & n.a. & n.a. & $93.2 \%$ & $60.7 \% * * *$ & $61.0 \% * * *$ \\
\hline Presence mother in law & $7.4 \%$ & $7.9 \%$ & $7.1 \%$ & n.a. & n.a. & $10.4 \%$ & $0.0 \% * * *$ & $0.3 \% * * *$ \\
\hline
\end{tabular}

Notes: sample weights applied; Based on two-sided p-values ***, **, * indicate significance levels at $1 \%, 5 \%$ and $10 \%$ respectively, and in comparison to first two columns "married in both years".

${ }^{a} \mathrm{~N}$ varies for some variables, depending on marital status at time of interview (some variables only applicable for women in union). As such, caution is needed in interpretation of results, due to low $\mathrm{N}$. 
Table A2. The effect of pregnancy loss and child mortality on the attitude towards spousal violence, including all women

\begin{tabular}{|c|c|c|}
\hline & (1) & (2) \\
\hline 0 children deceased & ref & ref \\
\hline 1 child deceased & $\begin{array}{c}0.037 \\
(0.151)\end{array}$ & $\begin{array}{l}-0.025 \\
(0.123)\end{array}$ \\
\hline $2+$ children deceased & $\begin{array}{c}0.187 \\
(0.180)\end{array}$ & $\begin{array}{c}0.090 \\
(0.153)\end{array}$ \\
\hline Pregnancy loss (nr in past 5 yrs) & $\begin{array}{c}-0.358 * * * \\
(0.107)\end{array}$ & $\begin{array}{c}-0.176 * \\
(0.094)\end{array}$ \\
\hline 0 children alive & ref & ref \\
\hline 1-3 children alive & $\begin{array}{l}-0.227 \\
(0.214)\end{array}$ & $\begin{array}{l}-0.229 \\
(0.147)\end{array}$ \\
\hline 4-5 children alive & $\begin{array}{c}-0.322 \\
(0.265)\end{array}$ & $\begin{array}{c}-0.393 * * \\
(0.199)\end{array}$ \\
\hline $6+$ children alive & $\begin{array}{l}-0.272 \\
(0.314)\end{array}$ & $\begin{array}{c}-0.478 * \\
(0.248)\end{array}$ \\
\hline \multicolumn{3}{|l|}{ Control variables } \\
\hline infecund & $\begin{array}{c}0.095 \\
(0.128)\end{array}$ & $\begin{array}{c}0.079 \\
(0.102)\end{array}$ \\
\hline Radio exposure & $\begin{array}{c}0.039 \\
(0.093)\end{array}$ & $\begin{array}{l}-0.000 \\
(0.074)\end{array}$ \\
\hline Wealth & $\begin{array}{c}0.071 * * \\
(0.100)\end{array}$ & $\begin{array}{c}0.148 * * \\
(0.068)\end{array}$ \\
\hline Year of survey & $\begin{array}{c}-0.388 * * * \\
(0.079)\end{array}$ & $\begin{array}{c}-0.295 * * * \\
(0.065)\end{array}$ \\
\hline Control over money & $\begin{array}{c}0.103 * * \\
(0.048)\end{array}$ & $\begin{array}{l}0.068^{*} \\
(0.041)\end{array}$ \\
\hline married & & ref \\
\hline Never married & & $\begin{array}{l}-.0222 \\
(0.159)\end{array}$ \\
\hline Separated/divorced/widowed & & $\begin{array}{c}0.140 \\
(0.152)\end{array}$ \\
\hline Constant & $\begin{array}{c}0.445 * * \\
(0.220)\end{array}$ & $\begin{array}{c}0.493 * * * \\
(0.164)\end{array}$ \\
\hline Number of observations & 994 & 1583 \\
\hline Number of groups & 504 & 800 \\
\hline F / Wald chi2 & 6.21 & 4.48 \\
\hline Prob > F / Wald chi2 & .0000 & .0000 \\
\hline R-square within / Pseudo R-square & .1264 & .0742 \\
\hline
\end{tabular}

Notes. Linear panel regression presented. Based on two-sided p-values ***, **, * indicate significance levels at $1 \%, 5 \%$ and $10 \%$ respectively; sampling weights applied. 
Table A3. Estimating effects with different time references

\begin{tabular}{|c|c|c|c|c|}
\hline & \multicolumn{2}{|c|}{$\begin{array}{l}\text { Spousal violence } \\
\text { (linear regression coef) }\end{array}$} & \multicolumn{2}{|c|}{$\begin{array}{l}\text { Control sexual } \\
\text { relationship } \\
\text { (odds ratios) } \\
\end{array}$} \\
\hline & $5 \mathrm{yr}$ & Ever & $5 \mathrm{yr}$ & Ever \\
\hline 0 children deceased & ref. & ref. & ref. & ref. \\
\hline 1 child deceased & $\begin{array}{c}0.013 \\
(0.116)\end{array}$ & $\begin{array}{c}0.026 \\
(0.155)\end{array}$ & $\begin{array}{c}0.680 \\
(0.290)\end{array}$ & $\begin{array}{l}0.415^{*} \\
(0.206)\end{array}$ \\
\hline $2+$ children deceased & $\begin{array}{l}-0.076 \\
(0.214)\end{array}$ & $\begin{array}{c}0.148 \\
(0.183)\end{array}$ & $\begin{array}{c}0.516 \\
(0.337)\end{array}$ & $\begin{array}{r}0.276^{* *} \\
(0.152)\end{array}$ \\
\hline Pregnancy loss ${ }^{\mathrm{a}}$ & $\begin{array}{c}-0.364 * * * \\
(0.109)\end{array}$ & $\begin{array}{l}-0.210^{*} \\
(0.117)\end{array}$ & $\begin{array}{c}1.233 \\
(0.536)\end{array}$ & $\begin{array}{l}1.600 \\
(0.766)\end{array}$ \\
\hline 0 children alive & ref. & ref. & ref. & ref. \\
\hline $1-3$ children alive (ever) / $1-2$ child $(5 \mathrm{yr})$ & $\begin{array}{l}-0.020 \\
(0.126)\end{array}$ & $\begin{array}{l}-0.273 \\
(0.216)\end{array}$ & $\begin{array}{c}1.104 \\
(0.405)\end{array}$ & $\begin{array}{c}0.605 \\
(0.471)\end{array}$ \\
\hline 4-5 children alive (ever) / $3+$ child ( 5 yr) & $\begin{array}{c}0.036 \\
(0.157)\end{array}$ & $\begin{array}{l}-0.372 \\
(0.263)\end{array}$ & $\begin{array}{c}1.709 \\
(0.913)\end{array}$ & $\begin{array}{c}0.816 \\
(0.744)\end{array}$ \\
\hline $6+$ children alive (ever) & n.a. & $\begin{array}{l}-0.341 \\
(0.313)\end{array}$ & n.a. & $\begin{array}{l}1.153 \\
(1.284)\end{array}$ \\
\hline \multicolumn{5}{|l|}{ Control variables } \\
\hline infecund & $\begin{array}{c}0.104 \\
(0.134)\end{array}$ & $\begin{array}{c}0.111 \\
(0.126)\end{array}$ & $\begin{array}{c}0.966 \\
(0.390)\end{array}$ & $\begin{array}{c}0.872 \\
(0.366)\end{array}$ \\
\hline Radio exposure & $\begin{array}{c}0.060 \\
(0.094)\end{array}$ & $\begin{array}{c}0.044 \\
(0.093)\end{array}$ & $\begin{array}{l}1.396 \\
(0.377)\end{array}$ & $\begin{array}{c}1.359 \\
(0.379)\end{array}$ \\
\hline Wealth & $\begin{array}{c}0.072 \\
(0.100)\end{array}$ & $\begin{array}{c}0.061 \\
(0.101)\end{array}$ & $\begin{array}{c}0.797 \\
(0.303)\end{array}$ & $\begin{array}{c}0.963 \\
(0.347)\end{array}$ \\
\hline Year of survey & $\begin{array}{c}-0.416^{* * *} \\
(0.063)\end{array}$ & $\begin{array}{c}-0.361 * * * \\
(0.081)\end{array}$ & $\begin{array}{c}0.238 * * * \\
(0.052)\end{array}$ & $\begin{array}{c}0.229 * * * \\
(0.063)\end{array}$ \\
\hline Control over money & $\begin{array}{c}0.112 * * \\
(0.048)\end{array}$ & $\begin{array}{c}0.097 * * \\
(0.049)\end{array}$ & $\begin{array}{l}1.169 \\
(0.164)\end{array}$ & $\begin{array}{c}1.237 \\
(0.179)\end{array}$ \\
\hline In polygynous marriage & $\begin{array}{l}0.181 \\
(0.152)\end{array}$ & $\begin{array}{l}0.162 \\
(0.153)\end{array}$ & $\begin{array}{l}4.703 * * \\
(3.363)\end{array}$ & $\begin{array}{r}5.853 * * \\
(4.232)\end{array}$ \\
\hline Spouse living in same house & $\begin{array}{l}-0.117 \\
(0.233)\end{array}$ & $\begin{array}{c}-0.97 \\
(0.233)\end{array}$ & $\begin{array}{l}6.370^{* *} \\
(5.472)\end{array}$ & $\begin{array}{l}5.834 * * \\
(4.983)\end{array}$ \\
\hline Presence mother-in-law & $\begin{array}{c}0.127 \\
(0.178)\end{array}$ & $\begin{array}{c}0.119 \\
(0.184)\end{array}$ & $\begin{array}{c}0.962 \\
(0.519)\end{array}$ & $\begin{array}{c}0.710 \\
(0.394)\end{array}$ \\
\hline Constant & $\begin{array}{r}0.294 \\
(0.282) \\
\end{array}$ & $\begin{array}{r}0.526 \\
(0.327) \\
\end{array}$ & n.a. & n.a. \\
\hline Number of observations & 994 & 994 & 428 & 428 \\
\hline F/ Chi2 & 5.49 & 4.70 & 63.55 & 61.48 \\
\hline Prob $>$ F / Prob > Chi 2 & 0.0000 & 0.0000 & 0.0000 & 0.0000 \\
\hline R2 within / Pseudo R2 & 0.1262 & 0.1198 & 0.3040 & 0.3241 \\
\hline
\end{tabular}

Notes: Models 3 and 4 present Condition logit estimates, odds ratios presented. Based on two-sided p-values $* * *, * *, *$ indicate significance levels at $1 \%, 5 \%$ and $10 \%$ respectively; sampling weights applied in all models.

${ }^{\text {a }}$ Pregnancy loss is measured by number of losses in past 5 years. For the second reference period, the number of losses is not known. As such, a dummy was created if the woman ever experienced a pregnancy loss. 


\section{NOTES}

1 Empowerment is broadly defined as women's ability to make decisions and to assert control over their own life and body (Kabeer, 1999). It comprises several domains: economic, socio-cultural, legal, political, psychological and interpersonal (Malhotra et al., 2002). Although these domains are interlinked, being empowered in one domain does not necessarily imply being empowered in another. This paper focuses on the interpersonal dimension of empowerment, which mostly includes relative power within the household, especially vis-à-vis a spouse. As such, this paper focuses on empowerment as the relative (dis)empowerment at the individual level, as opposed to women as social class within (an unequal gendered) society.

2 While some scholars consider bodily integrity as a prerequisite for empowerment (Mathur, 2008), or as capability or human or sexual right (Nussbaum, 2003, Robeyns, 2011, Sen and Batliwala, 2000), we consider bodily integrity as part of the interpersonal domain of empowerment (Lee-Rife, 2010).

3 Health staff is also found to blame women for delaying care-seeking and poor birth outcomes (Béhague et al., 2008). As such, women experience power inequities at several levels: within their marriage and within the patient-health care provider relationship.

4 Lee-Rife (2010) examined the effects of reproductive health events on women's empowerment in India. She specifically studies the influence of unwanted and mistimed pregnancy, miscarriage, stillbirths and abortions on the mobility, financial decision-making, experiences of violence and the threats of abandonment. She finds a strong correlation between abortion and violence.

5 The National Bureau of Statistics in Tanzania (NBS) is the original collector of the TDHS and the authorised distributor of the data. For this study, we partnered with the Muhimbili University for Health and Allied Sciences (MUHAS), who contacted the NBS to explore possibilities to build upon the TDHS of 2004, and to collect a second wave. The NBS responded positively and provided the information required to revisit the women interviewed in the Lake Zone Region. This included the names of the enumeration areas, as well as the names of the household members listed in the household roster. As the NBS collected the data in 2004, regional officers of the NBS visited the enumeration areas to track the women to be interviewed, and to ask for permission and consent for the re-interview. Before the visit by our data collectors, the respondents were first informed by their local leaders, and at the start of the interview, consent was asked again by the researchers. The data collectors did not have access to the full data set, and were only provided with information to identify the correct respondents, i.e. name and age of the woman in 2004, as well as names and 
ages of the household members listed in 2004 as control questions. After data collection, personal identifiers were deleted. Whereas the DHS 2004 collected some medically related data (i.e. height, weight, hemoglobine levels), this information was not used and not collected in 2010. The panel data set is authorised by MUHAS. Next to collaboration with the NBS, a research permit from the Tanzanian Commission for Sciences and Technology (COSTECH), a temporary residence permit, an ethical clearance from MUHAS, and consent from regional and district officers were obtained.

6 More specifically, we apply a panel fixed effects model estimating within group effects, i.e. for each variable the distance to the mean of that individual is calculated.

7 No difference was made between spontaneous and induced abortion and stillbirth. The question used was: 'Have you ever had a pregnancy that was miscarried, was aborted, or ended in a stillbirth?' Subsequently, every pregnancy and termination was noted in a calendar, from which we derived the number of pregnancy losses in the five years previous to the interview.

8 Common control variables in such analyses also include age and educational level. Age is strongly related to reproductive health, such as the number of pregnancies, and maternal education is an important resource for women's empowerment. Yet, as the change in age is the same for all women, and because educational level virtually remains constant over time, these variables are left out from the fixed effects models.

9 The reduction of bodily integrity seems to be region specific though. National DHS reports from 2004 and 2010 show a slight improvement in bodily integrity nationwide, but a negative trend in the Lake Zone region (NBS, 2011, NBS, 2005).

${ }^{10}$ For the variable indicating one child deceased, the two-side p-value is 0.100 in model 5. Considering our hypothesis, it could be argued we could take the one side p-value of 0.050 . 